\title{
Pengaruh Implementasi Variabel Crime Prevention Through Enviromental Design terhadap Persepsi Rasa Aman Penghuni Perumahan Wisma Permai Timur Surabaya
}

\author{
Bayu Munggaran dan Ardy Maulidy Navastara \\ Departemen Perencanaan Wilayah dan Kota, Fakultas Arsitektur, Desain dan Perencanaan, \\ Institut Teknologi Sepuluh Nopember \\ e-mail: ardy.navastara@urplan.its.ac.id
}

\begin{abstract}
Abstrak-Permukiman dan kriminalitas menjadi hal yang penting untuk diteliti karena perumahan sebagai tempat tinggal bagi masyarakat, menyimpan potensi menjadi ruang yang tidak aman (dari kriminalitas),dan hal ini menjadi isu terutama di kota-kota besar,baik itu di Indonesia maupun di luar Indonesia. Perumahan Wisma Permai Timur sebagai salah satu perumahan yang menerapkan Konsep Crime Prevention Through Enviromental Design atau CPTED, lalu apakah dengan penerapan CPTED ini akan mempengaruhi persepsi rasa aman penghuninya. Adapun tujuan dari penelitian ini adalah untuk menggambarkan bagaimana hubungan yang terbentuk antara rasa aman dan penerapan variabel CPTED. Dalam penelitian ini Metodologi yang digunakan dalam penelitian adalah metode campuran dengan pendekatan rasionalitstik, pertama adalah melakukan pengamatan di lapangan untuk mengidentifikasi apa yang sudah diterapkan di perumahan khususnya dalam koridor CPTED. Langkah selanjutnya adalah menentukan tingkat penerapan variabel CPTED dan selanjutnya akan dicari hubungan atau keterkaitannya melalui uji korelasi, dan regresi linear berganda. Berdasarkan serangkaian analisis didapatkan bahwa terdapat hubungan antara variabel CPTED yang diterapkan di perumahan wisma permai timur. Yang pada akhirnya merujuk pada suatu rekomendasi dimana variabel penguatan teritori adalah yang paling mempengaruhi, sehingga aspek penguatan identitas baik dari elemen fisik maupun non fisik adalah yang paling mempengaruhi rasa aman penghuni perumahan wisma permai timur.
\end{abstract}

Kata Kunci-Desain Lingkungan, Kriminalitas, Rasa Aman.

\section{PENDAHULUAN}

$P^{\prime}$ ERUMAHAN sebenarnya diharapkan merupakan suatu tempat yang aman, termasuk aman dari berbagai gangguan kejahatan. Lingkungan perumahan kota dibangun dengan pertimbangan keamanan terhadap bahaya, termasuk juga keamanan terhadap bahaya kriminal, sehingga aktivitas penghuninya dapat terwadahi secara maksimal seperti kegiatan bermukim, bekerja, bersosialisasi, beristirahat dan berekreasi [1].

Kejahatan bisa terjadi dimanapun, kapanpun dan siapapun. Salah satunya adalah di lingkungan perumahan. Berdasarkan penelitian dari Badan Pusat Statistik, dalam laporan Statistik Kriminal tahun 2009, menunjukan bahwa kejahatan yang terjadi di rumah tangga mencapai 1.854.122, dimana untuk jenis kasus pencurian pada peringkat pertama dengan 1.367.452 kali, dan disusul perampokan sebanyak 74.497 kasus di posisi kedua [2]. Dari laporan tersebut memperlihatkan bahwa lingkungan perumahan bukan tempat yang selalu mampu menghadirkan perasaan aman bagi para penghuninya. Kondisi lingkungan yang tidak aman tentu akan mempengaruhi perasaan tidak aman bagi penghuninya. Keadaan lingkungan dapat mempengaruhi rasa aman orang-orang yang berada di dalamnya [3].

Rasa aman merupakan hal yang penting bagi seseorang, dikarenakan apabila seseorang merasa terancam dan takut itu akan membuat sesorang berperilaku tertutup, tidak mempercayai orang lain dan lingkungannya, menolak untuk berbicara dengan orang asing, ragu-ragu terhadap hal baru, serta ragu ketika menghadapi situasi baru [4]. Dengan timbulnya rasa tidak aman ini sendiri akan menyebabkan disorganisasi sosial pada lingkungan permukiman. Dengan meningkatkan rasa aman dalam ruang lingkup perumahan akan mendorong seseorang untuk mengambil kendali terhadap lingkungannya dan memungkinkan adanya interaksi antar penghuni di lokasi perumahan.

Wilayah studi yaitu perumahan Wisma Permai Timur adalah salah satu perumahan yang berada di Kota Surabaya tepatnya di kecamatan Mulyorejo. Mulyorejo merupakan salah satu wilayah rayon yang di identifikasi rawan kriminalitas . Sejumlah kejadian kriminalitas kerap terjadi di lingkungan perumahan Wisma Permai Timur. Lokasi perumahan yang strategis dan sering dilalui kendaraan sebagai jalan penghubung antara pusat kegiatan menjadikan lingkungan perumahan lebih rentan untuk dimasuki oleh pelaku kejahatan. Penjagaan yang dilakukan oleh petugas keamanan pun tidak terlalu sigap, pada siang hari petugas keamanan hanya bertugas di pos tidak adanya pemerikasaan keluar masuk maupun patroli. Ini tentu saja berpotensi menjadikan wilayah wisma permai timur sebagai sasaran tindak kriminalitas. Namun ditemukan juga beberapa implementasi pengamanan yang diantaranya masuk kedalam konsep CPTED. Karakteristik masyarakat yang tinggal pada Kompleks Perumahan Wisma Permai Timur sudah bersifat kekotaan, akan tetapi interaksi antar masyarakat perumahan yang ditemukan di lapangan sangat baik hal ini terlihat dari seringnya melakukan kegiatan bersama, tentu saja ini merupakan identitas sendiri dimana kategori perumahan yang tergolong menengah keatas, dan karakteristik masyarakat yang bersifat kekotaan. Dengan kondisi perumahan yang seperti itu maka peneliti memilih Kompleks Perumahan Wisma Permai Timur sebagai wilayah studi. 
Kemudian dari fakta tentang kondisi lingkungan perumahan Wisma permai Timur yang kerap terjadi tindak kriminalitas tentu akan mempengaruhi perasaan aman penghuninya dan CPTED merupakan salah satu konsep yang bisa mempengaruhi tingkat kriminalitas di suatu lingkungan. Dari rumusan masalah tersebut muncul pertanyaan yang menjadi fokusan untuk penelitian ini, yaitu adakah hubungan desain lingkungan perumahan berdasarkan konsep CPTED terhadap persepsi rasa aman penghuni perumahan Wisma Permai Timur. Tujuan dari penelitian ini adalah untuk menjelaskan bagaimana hubungan yang terbentuk antara penerapan Crime Prevention Through Enviromental Design di lingkungan perumahan Wisma Permai Timur terhadap persepsi rasa aman masyarakat di perumahan Wisma Permai Timur.

\section{II.METODE PENELITIAN}

\section{A. Jenis dan Pendekatan Penelitian}

Pendekatan yang digunakan dalam penelitian ini adalah pendekatan rasionalistik. Penelitian ini menggunakan metode penelitian campuran atau mixed method.

\section{B. Variabel Penelitian}

Variabel penelitian yang digunakan pada tahapan penelitian ini adalah variabel yang ada pada konsep CPTED yaitu variabel Kontrol Akses, variabel Pengawasan, dan variabel Penguatan Teritori, serta variabel Rasa Aman penghuni.

\section{CPTED dan Rasa Aman}

Dalam buku 21st Century Security and CPTED, Atlas menjelaskan bahwa CPTED adalah konsep yang berfokus pada;

1. Lingkungan fisik, yaitu keadaan fisik lingkungan yang dapat dimanipulasi untuk menghasilkan efek perilaku yang akan mengurangi ketakutan dan terjadinya tindak kejahatan. Contoh penerapannya adalah penggunaan pagar.

2. Perilaku orang-orang dengan lingkungan fisik lingkungannya, beberapa lokasi sepertinya mencermikan terjadi kesempatan untuk dilakukan tindak kejahatan, dan yang lainnya tidak.

3. Mendesain ulang atau menggunakan area yang ada lebih efektif lagi untuk mendorong perilaku yang diinginkan dan mencegah perilaku yang tidak diinginkan.

Crowe, dengan pengalamannya terhadap peneilitian dalam bidang CPTED secara umum mengusulkan tiga dasar langkah-langkah dalam CPTED;

1. Langkah mekanik, dengan memberikan hambatan terhadap target, seperti penggunaan kunci, sistem alarm, penggunaan pagar maupun pintu gerbang

2. Organisasional atau langkah yang bersifat manusia, yaitu dengan cara sosialisasi penanganan kejahatan atau tindakan perlindungan diri dan harta benda. Bisa juga melalui interaksi individu dengan lingkungan maupun individu lainnya. Seperti patroli malam atau kegiatan warga. Langkah organisasional lebih menekankan kepada orang-orang di dalam lingkungan tersebut.

3. Langkah natural, yaitu dengan membuat desai lingkungan yang efektif bagi semua penggunaannya. Langkah natural merupakan langkah lebih lanjut apabila langkah mekanik dan organisasional sudah diterapkan, sehingga tercipta lingkungan yang secara alami mendukung konsep CPTED.

Adapun konsep CPTED yang berkembang saat ini berkembang lebih kepada perpanjangan konsep Defensible Space [5]. Serupa dengan Jeffrey, Crowe menyatakan bahwa konsep CPTED merupakan konsep yang mirip dengan Defensible Space, yaitu dengan penerapan natural access control, natural surveillance dan juga territorial reinforcement, konsep CPTED memodifikasi dan mengembangkan konsep Defensible Space terhadap niaga komersil, institusi industri, dan perumahan dengan kepadatan penduduk rendah [6].

Tabel 1.

Sintesa Pustaka

\begin{tabular}{|c|c|c|}
\hline Konsep & Variabel & Indikator \\
\hline \multirow{13}{*}{ CPTED } & \multirow{6}{*}{ Kontrol akses } & Letak Permukiman \\
\hline & & $\begin{array}{l}\text { Akses keluar masuk lingkungan } \\
\text { perumahan }\end{array}$ \\
\hline & & $\begin{array}{l}\text { Penggunaan portal atau pagar keluar } \\
\text { masuk }\end{array}$ \\
\hline & & $\begin{array}{l}\text { Pengecekan, pemantauan keluar masuk } \\
\text { perumahan }\end{array}$ \\
\hline & & $\begin{array}{l}\text { Penggunaan pembatas dengan lingkungan } \\
\text { sekitar }\end{array}$ \\
\hline & & Perangkat penguncian \\
\hline & \multirow{3}{*}{ Pengawasan } & Patroli dan sistem personil keamanan \\
\hline & & $\begin{array}{l}\text { Kondisi fisik perumahan yang mudah } \\
\text { diawasi }\end{array}$ \\
\hline & & $\begin{array}{l}\text { Fasilitas tambahan yang membantu } \\
\text { pengawasan }\end{array}$ \\
\hline & \multirow{4}{*}{$\begin{array}{l}\text { Penguatan } \\
\text { Teritori }\end{array}$} & $\begin{array}{l}\text { Penanda batas antara lingkungan } \\
\text { perumahan dan sekitarnya }\end{array}$ \\
\hline & & $\begin{array}{l}\text { Sarana kegiatan bersama antar penghuni } \\
\text { perumahan }\end{array}$ \\
\hline & & Interaksi antar penghuni \\
\hline & & Rasa memiliki lingkungan \\
\hline \multirow{3}{*}{$\begin{array}{l}\text { Persepsi } \\
\text { Rasa Aman }\end{array}$} & Tingkat & Dalam Hal Kontrol akses \\
\hline & Persepsi Rasa & Dalam Hal Pengawasan \\
\hline & Aman & Dalam Hal Penguatan Teritori \\
\hline
\end{tabular}

Tabel 2.

Alur Penelitian

\begin{tabular}{|c|c|c|c|c|}
\hline Sasaran & Input data & Tujuan & $\begin{array}{c}\text { Teknik/Metode } \\
\text { Analisa }\end{array}$ & $\begin{array}{l}\text { Output } \\
\text { Analisa }\end{array}$ \\
\hline $\begin{array}{c}\text { Identifikasi } \\
\text { bentuk } \\
\text { penerapan } \\
\text { CPTED di } \\
\text { lingkungan } \\
\text { Perumahan } \\
\text { Wisma } \\
\text { Permai Timur }\end{array}$ & $\begin{array}{l}\text { Hasil } \\
\text { observasi } \\
\text { di } \\
\text { lapangan }\end{array}$ & $\begin{array}{l}\text { Mengetahui dan } \\
\text { mengidentifikasi } \\
\text { apa saja } \\
\text { bentuk-bentuk } \\
\text { penerapan } \\
\text { variabel CPTED } \\
\text { di lokasi } \\
\text { perumahan } \\
\text { wisma permai } \\
\text { timur }\end{array}$ & $\begin{array}{c}\text { Analisis } \\
\text { Deskriptif } \\
\text { Kualitatif }\end{array}$ & $\begin{array}{c}\text { Gambaran } \\
\text { deskriptif } \\
\text { tentang } \\
\text { bentuk } \\
\text { penerapan } \\
\text { variabel } \\
\text { CPTED } \\
\text { serta } \\
\text { persepsi } \\
\text { rasa aman }\end{array}$ \\
\hline $\begin{array}{l}\text { mengetahui } \\
\text { tingkat } \\
\text { implementasi } \\
\text { variabel } \\
\text { CPTED dan } \\
\text { persepsi rasa } \\
\text { aman } \\
\text { penghuni }\end{array}$ & $\begin{array}{l}\text { kuesioner } \\
\text { dan hasil } \\
\text { observasi }\end{array}$ & $\begin{array}{l}\text { Mengetahui } \\
\text { tingkat } \\
\text { penerapan } \\
\text { variabel CPTED } \\
\text { terhadap persepsi } \\
\text { rasa aman }\end{array}$ & $\begin{array}{c}\text { Analisis } \\
\text { deskriptif } \\
\text { kualitatif }\end{array}$ & $\begin{array}{l}\text { Tingkat } \\
\text { penerapan } \\
\text { variabel } \\
\text { CPTED } \\
\text { dan persepi } \\
\text { rasa aman }\end{array}$ \\
\hline $\begin{array}{l}\text { Mengetahui } \\
\text { bentuk dan } \\
\text { tingkat } \\
\text { hubungan } \\
\text { antara } \\
\text { penerapan } \\
\text { variabel } \\
\text { CPTED } \\
\text { terhadap } \\
\text { persepsi rasa }\end{array}$ & Kuesioner & $\begin{array}{l}\text { Mengetahui } \\
\text { bentuk dan } \\
\text { tingkat hubungan } \\
\text { antara penerapan } \\
\text { variabel CPTED } \\
\text { terhadap persepsi } \\
\text { rasa aman } \\
\text { penghuni } \\
\text { perumahan }\end{array}$ & $\begin{array}{c}\text { Analisis } \\
\text { korelasi dan } \\
\text { tabulasi silang }\end{array}$ & $\begin{array}{c}\text { Tingkat } \\
\text { korelasi } \\
\text { dan bentuk } \\
\text { hubungan } \\
\text { variabel x } \\
\text { dan y }\end{array}$ \\
\hline
\end{tabular}




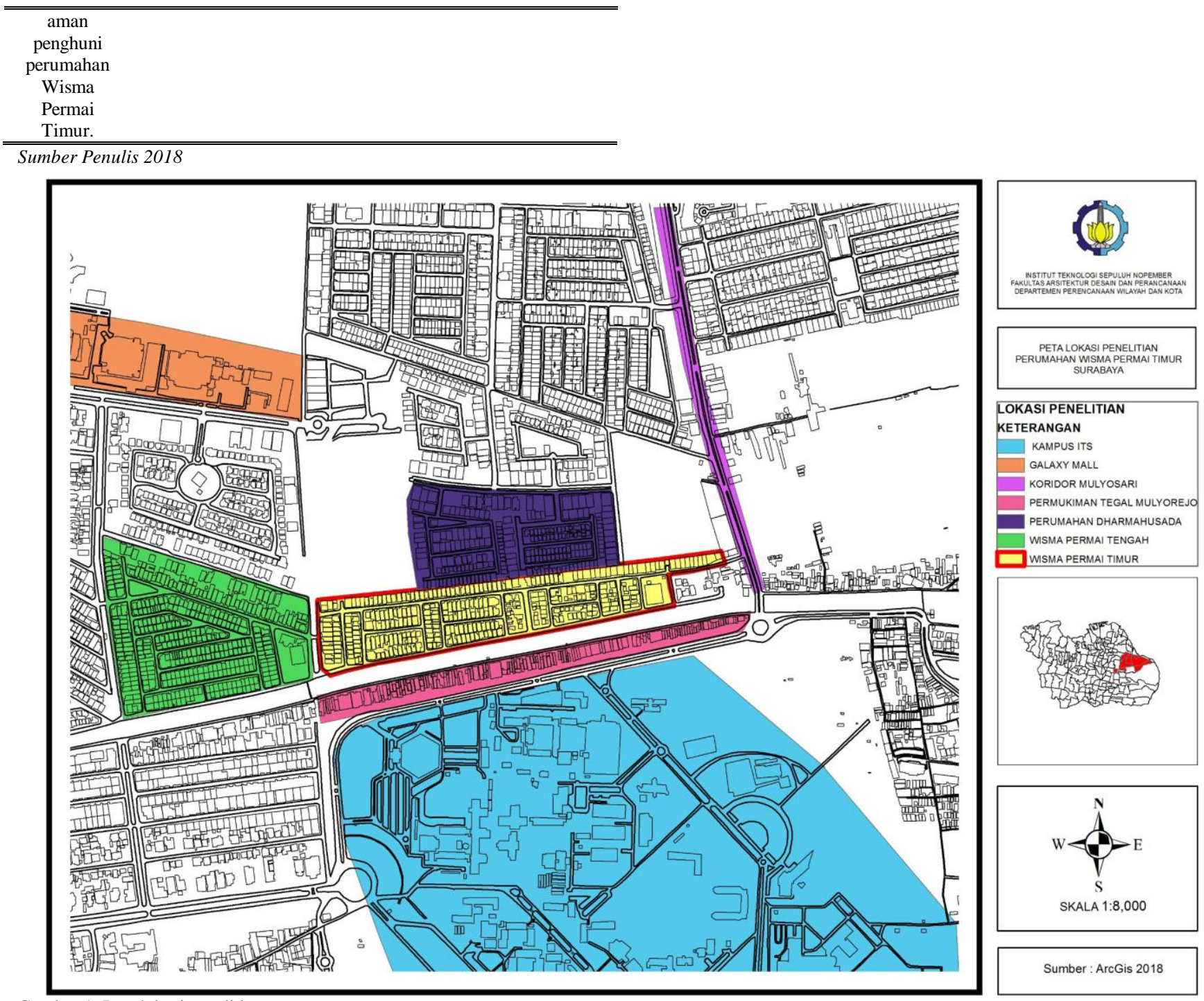

Gambar 1. Peta lokasi penelitian.

\section{HASIL DAN DISKUSI}

A.Identifikasi Bentuk Implementasi Variabel CPTED di Perumahan Wisma Permai Timur

\section{Kontrol Akses}

Berdasarkan hasil pengamatan di lokasi penelitian adapun penerapan langkah-langkah kontrol akses, yaitu dimana terciptanya suatu kondisi yang ditekankan pada elemen fisik maupun non fisik sehingga akses keluar masuk dibatasi. Pada perumahan Wisma Permai Timur pembatasan akses keluar masuk dapat dilihat dari terdapatnya pagar pembatas di sekeliling perumahan, terdapatnya pintu gerbang untuk akses keluar masuk di bagian barat dan timur perumahan, terdapat bentang alam yaitu sungai kalimas, serta bentang buatan berupa tembok besar yang membatasi perumahan dengan perumahan dharmahusada mas, dan adanya pemeriksaan di pintu akses oleh petugas keamanan.
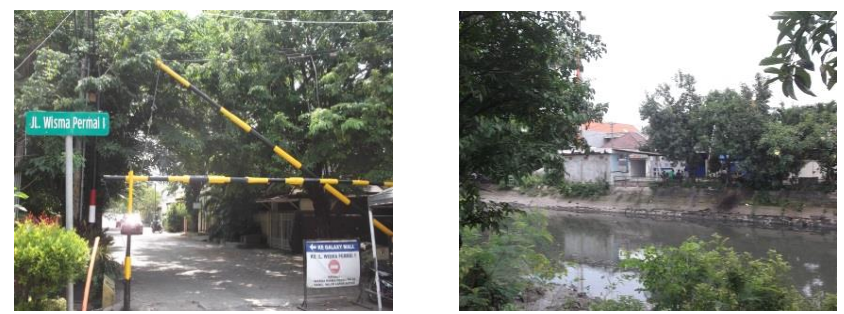

Gambar 2. Penerapan variabel kontrol akses.
Lokasi perumahan yang berdekatan dengan beberapa pusat kegiatan dan dilalui oleh jalan umum berpotensi menjadikan perumahan wisma permai sebagai target pelaku potensial kejahatan, karena akan sulit melakukan identifikasi terhadap lingkungan sekitar saat ramai. Pembatasan titik akses adalah salah satu langkah yang tepat untuk mengakali kondisi perumahan wisma permai seperti yang sudah dijelaskan sebelumnya.

\section{Pengawasan}

Berdasarkan hasil pengamatan di lokasi penelitian adapun penerapan langkah-langkah pengawasan di perumahan wisma permai dapat dilihat dari penggunaan fasilitas tambahan, lalu sistem patroli, dan keberadaan petugas.
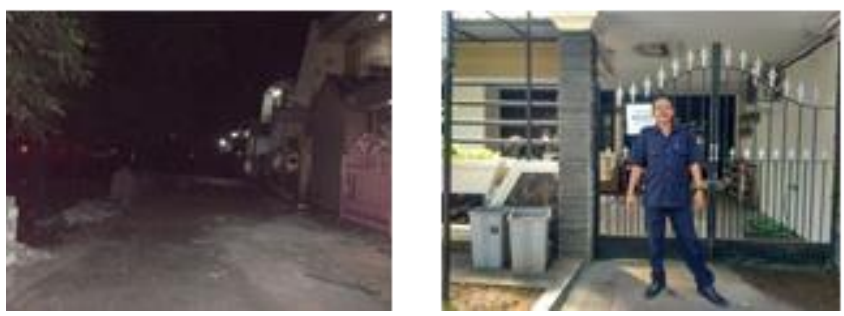

Gambar 3. Penerapan variabel pengawasan. 
Penerapan langkah pengawasan juga dapat dilihat dari kondisi penghijuan yang mendukung proses berlangsungnya pengawasan ke lingkungan sekitar perumahan. Kondisi perumahan yang sepi dsn jauh dari kantor polisi serta kondisi penerangan yang kurang baik pada malam hari merupakan beberapa celah yang dapat dimanfaatkan oleh pelaku potensial kejahatan

\section{Penguatan Teritori}

Berdasarkan hasil pengamatan di lokasi penelitian adapun penerapan langkah-langkah penguatan teritori yang ada di perumahan wisma permai timur bukan hanya pada aspek fisik melainkan aspek sosial seperti kegiatan bersama antar penghuni. Kuatnya interaksi antar penghuni akan mempermudah penghuni mengidentifikasi siapa saja orang lain yang memasuki kawasan perumahan. Adanya penanda perumahan di bagian masuk keluar perumahan juga memperkuat identitas dari suatu wilayah.
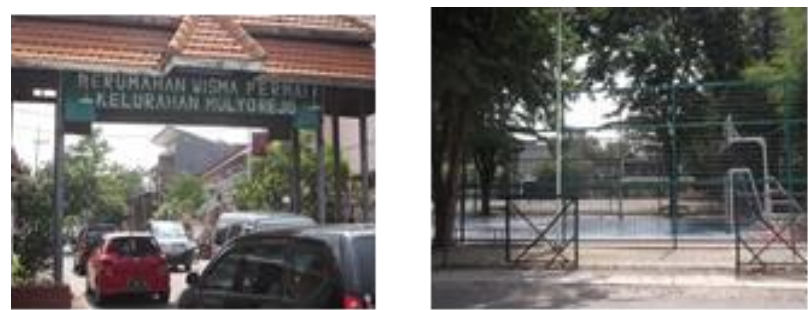

Gambar 3. Penerapan variabel penguatan teritori.

\section{B.Tingkat Penerapan Variabel Berdasarkan Persepsi Penghuni}

Setelah dilakukan observasi di lapangan terkait implementasi varriabel apa saja yang ditemukan. Peneliti membuat kuesioner yang diberikan kepada responden. Adapun responden berjumlah 90 orang yang didapat dari perhitungan rumus slovin yang kemudian dilakukan stratified random sampling terhadap 6 RT yang sudah dibagi proporsinya.

1. Kontrol Akses

Tabel 2

Rekap Hasil Kuesioner Kontrol Akses

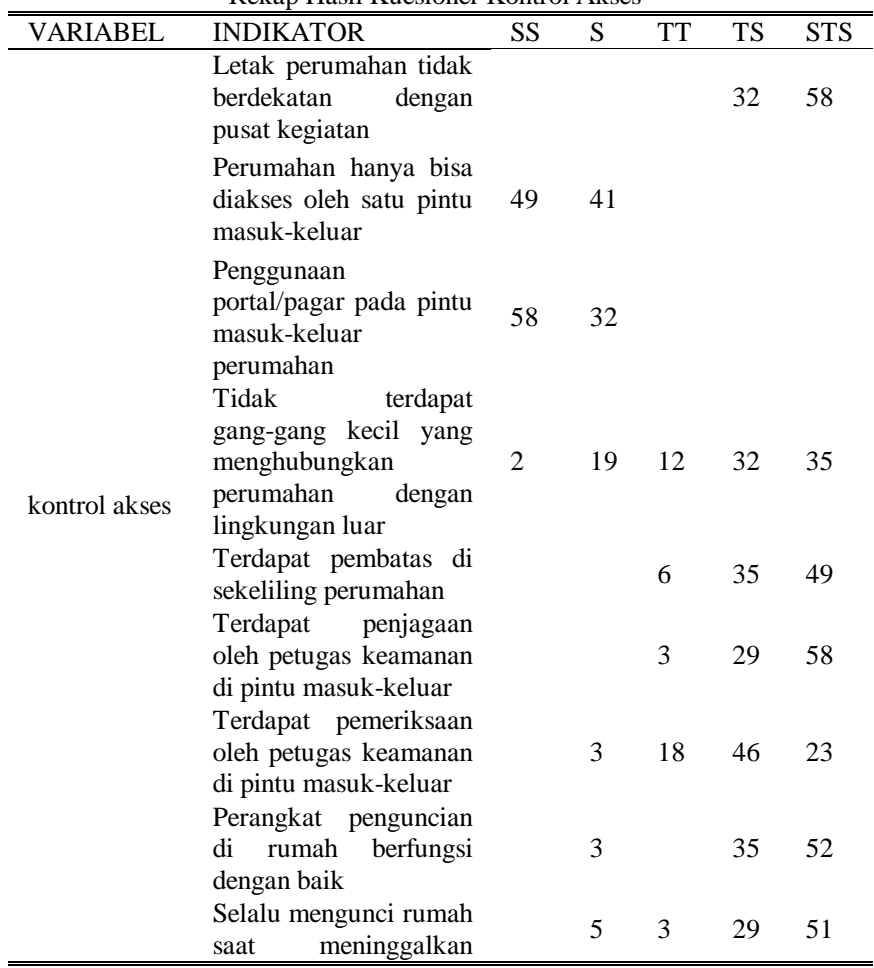

rumah

Setelah dilakukan rekap kuesioner lalu kemudian menentukan tingkat penerapan dari masing-masing veriabel. Adapaun dalam prosesnya menggunakan metode skoring. Skoring dilakukan dengan memberikan poin 5 untuk jawaban sangat sesuai, kemudian poin 1 untuk jawaban sangat tidak sesuai.

Sehingga didapatkan hasil bahwa tingkat penerapan tinggi apabila lebih dari 18, atau rendah apabila kurang dari 18 . Dari hasil tersebut dapat disimpulkan bahwa dari 90 responden, sebesar $100 \%$ atau seluruhnya mewakili tingkat penerapan variabel kontrol akses yang tinggi. Hal ini dapat dilihat dari pernyataan responden sebelumnya, yang memperlihatkan adanya unsur-unsur kontrol akses yang diterapkan di lingkungannya. Seperti perangkat penguncian, penggunaan portal, pembatas, penjagaan dan pemeriksaan oleh petugas, serta tidak adanya gang-gang kecil diperumahan.

2. Pengawasan

Tabel 3

Rekap Hasil Kuesioner Pengawasan

\begin{tabular}{|c|c|c|c|c|c|c|}
\hline VARIABEL & 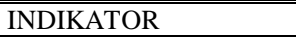 & $\overline{\mathrm{SS}}$ & $\bar{S}$ & TT & $\mathrm{TS}$ & STS \\
\hline & $\begin{array}{l}\text { Keberadaan petugas } \\
\text { keamanan di lingkungan } \\
\text { perumahan }\end{array}$ & & & 14 & 31 & 45 \\
\hline & $\begin{array}{l}\text { Patroli kemanan oleh } \\
\text { petugas }\end{array}$ & & & 16 & 35 & 39 \\
\hline & $\begin{array}{l}\text { Kondisi penghijauan tidak } \\
\text { menghalangi pandangan }\end{array}$ & 4 & 22 & 8 & 44 & 12 \\
\hline \multirow[t]{4}{*}{ Pengawasan } & $\begin{array}{l}\text { Kondisi penerangan yang } \\
\text { baik pada malam hari di } \\
\text { lingkungan perumahan }\end{array}$ & & 1 & 1 & 67 & 21 \\
\hline & $\begin{array}{l}\text { Kondisi penerangan di } \\
\text { rumah berfungsi baik }\end{array}$ & & 1 & 3 & 58 & 28 \\
\hline & $\begin{array}{l}\text { Tidak terdapat ruang yang } \\
\text { sulit diawasi maupun } \\
\text { gelap di lingkungan }\end{array}$ & 3 & 39 & 30 & 15 & 3 \\
\hline & $\begin{array}{l}\text { Menggunakan fasilitas } \\
\text { pengawasan tambahan }\end{array}$ & 4 & 22 & 8 & 44 & 12 \\
\hline
\end{tabular}

Setelah dilakukan rekap kuesioner lalu kemudian menentukan tingkat penerapan dari masing-masing veriabel. Adapaun dalam prosesnya menggunakan metode skoring. Skoring dilakukan dengan memberikan poin 5 untuk jawaban sangat sesuai, kemudian poin 1 untuk jawaban sangat tidak sesuai.

Sehingga didapatkan hasil bahwa tingkat penerapan tinggi apabila lebih dari 14, atau rendah apabila kurang dari 14. Dari hasil tersebut dapat disimpulkan bahwa dari 90 responden, sebesar $100 \%$ atau seluruhnya mewakili tingkat penerapan variabel pengawasan yang tinggi. Penerapan pengawasan yang baik tentunya akan berhubungan dengan keamanan bagi orang-orang yang berada dalam lingkungan tersebut. Dimana terdapatnya titik atau desain lingkungan yang menciptakan ruang yang mudah diawasi berpotensi dijadikan tempat berkegiatan yang tidak diinginkan 3. Penguatan Teritori

Tabel 4.

Rekap Hasil Kuesioner Penguatan Teritori

\begin{tabular}{|c|c|c|c|c|c|c|}
\hline VARIABEL & "INDIKATOR & SS & $\bar{S}$ & TT & TS & STS \\
\hline \multirow[t]{2}{*}{ Penguatan } & $\begin{array}{l}\text { Penggunaan } \\
\text { identitas atau penanda } \\
\text { pada lokasi perumahan }\end{array}$ & 3 & 14 & 18 & 40 & 15 \\
\hline & $\begin{array}{l}\text { Mengenal tetangga di } \\
\text { sekitar rumah }\end{array}$ & & 12 & 4 & 62 & 12 \\
\hline
\end{tabular}




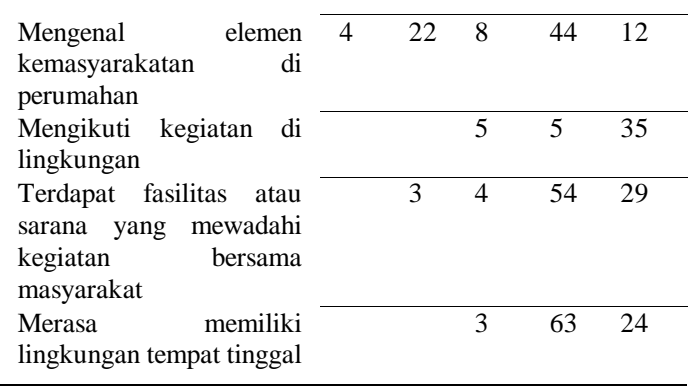

Setelah dilakukan rekap kuesioner lalu kemudian menentukan tingkat penerapan dari masing-masing veriabel. Adapaun dalam prosesnya menggunakan metode skoring. Skoring dilakukan dengan memberikan poin 5 untuk jawaban sangat sesuai, kemudian poin 1 untuk jawaban sangat tidak sesuai.

Sehingga didapatkan hasil bahwa tingkat penerapan tinggi apabila lebih dari 12, atau rendah apabila kurang dari 12. Dari hasil tersebut dapat disimpulkan bahwa dari 90 responden, sebesar $100 \%$ atau seluruhnya mewakili tingkat penerapan variabel penguatan teritori yang tinggi.

4. Persepsi Rasa Aman

Tabel 5.

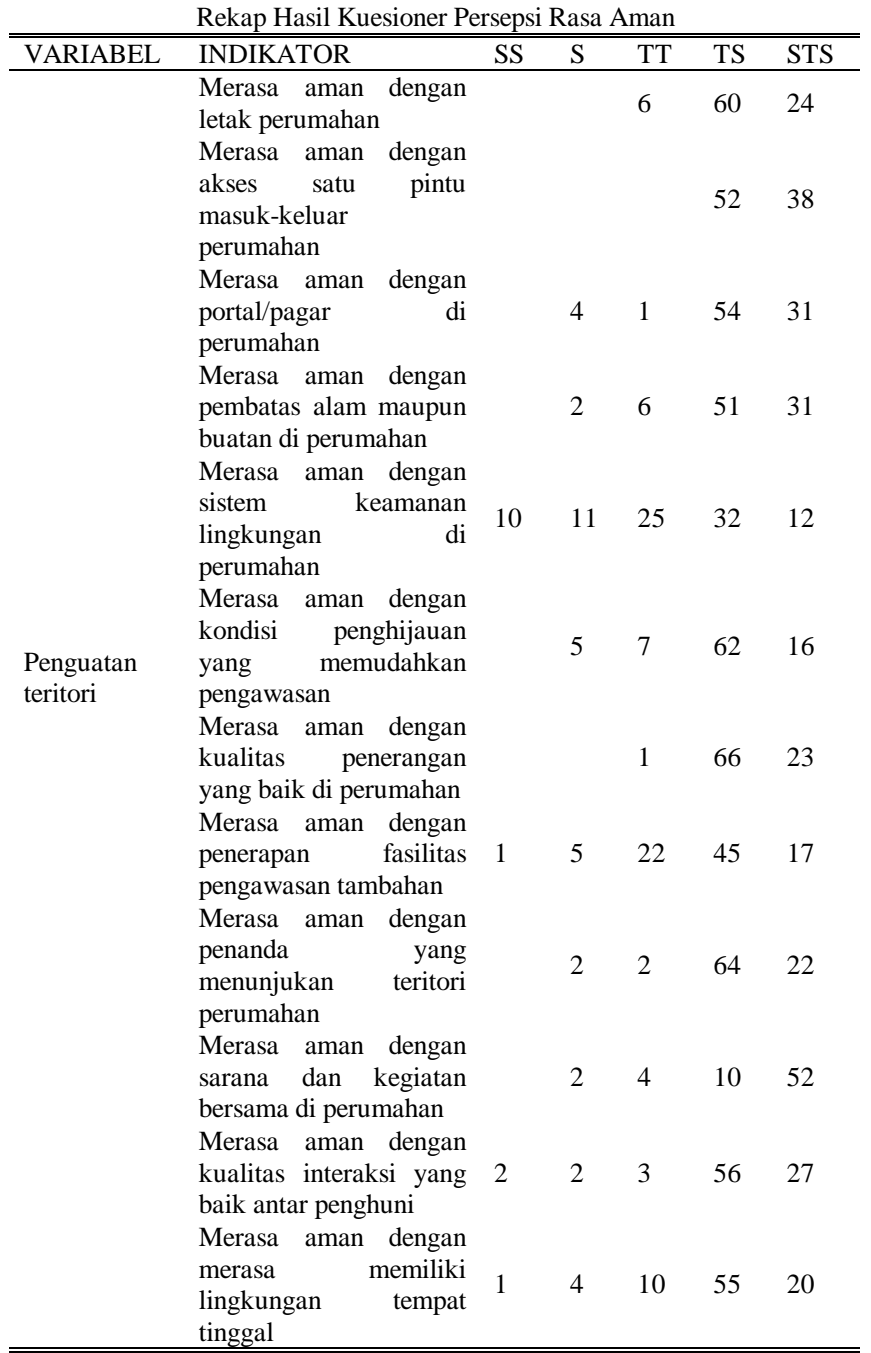

Setelah dilakukan rekap kuesioner lalu kemudian menentukan tingkat penerapan dari masing-masing veriabel. Adapaun dalam prosesnya menggunakan metode skoring. Skoring dilakukan dengan memberikan poin 5 untuk jawaban sangat sesuai, kemudian poin 1 untuk jawaban sangat tidak sesuai.
Sehingga didapatkan hasil bahwa tingkat penerapan tinggi apabila lebih dari 24, atau rendah apabila kurang dari 24 . Dari hasil tersebut dapat dilihat bahwa dari 90 responden, sebesar $100 \%$ atau seluruhnya mewakili tingkat persepsi rasa aman yang tinggi.

Rasa aman adalah suatu rasa yang lebih pada situasi psikologis, dan akan lebih menjadi keyakinan akan keamanan dengan adanya sitem-sistem pengamanan yang terpadu dan modern. Persepsi aman dalam penelitian ini merupakan hasil dari cara pandang penghuni perumahan terhadap rasa aman yang dirasakan terkait lingkungan tempat tinggalnya. Pada penelitian ini responden diminta untuk melihat bagaimana keadaan lingkungannya berdasarkan konsep CPTED, kemudian diminta untuk menanggapi situasi tertentu dan mengaitkannya dengan rasa aman yang tercipta dari situasi tersebut.

\section{C.Bentuk Hubungan Antara Variabel CPTED Terhadap Persepsi Rasa Aman}

Tabel 6. Uji Korelasi

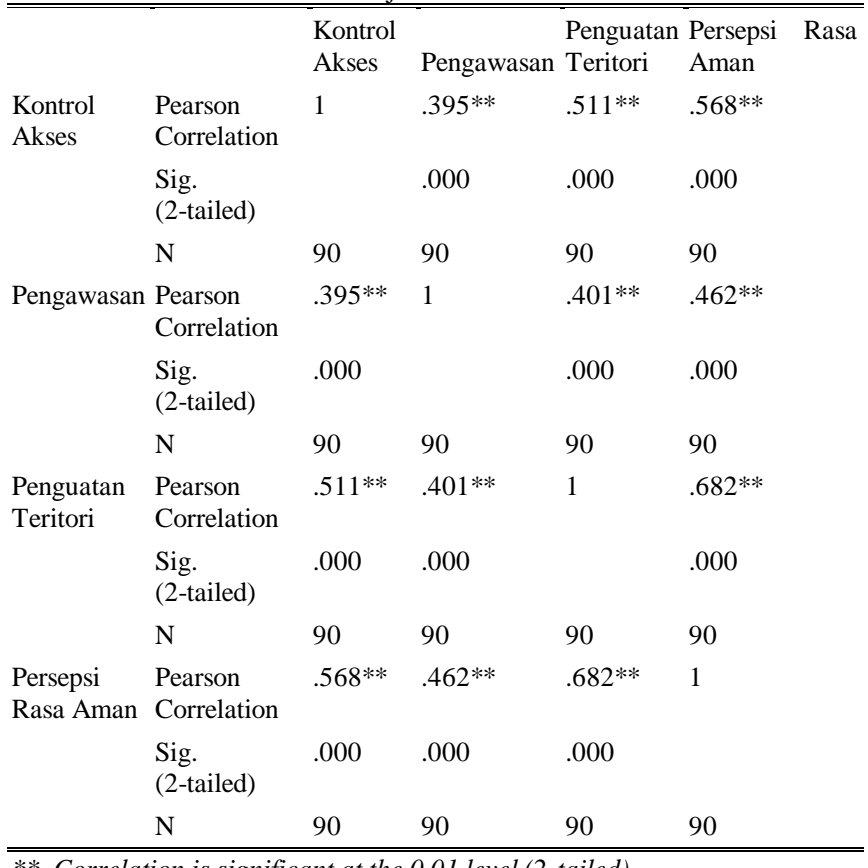
Sumber : Output SPSS 2018

Dari Tabel 6 merupakan Tabel korelasi yang memperlihatkan hubungan antara penerapan CPTED dengan persepsi rasa aman penghuni perumahan Wisma Permai Timur. Dari Tabel 4.6 dapat dilihat hubungan antara kontrol akses yang diterapkan di perumahan Wisma Permai Timur dengan persepsi rasa aman diperoleh nilai Sig. (2-tailed) sebesar 0.000 yang berarti kurang dari 0,05, artinya Ho ditolak, dan Ha (Terdapat hubungan antara kontrol akses terhadap rasa aman penghuni perumahan Wisma Permai Timur) diterima. Jadi terdapat hubungan antara kontrol akses yang diterapkan di perumahan Wisma Permai Timur dengan persepsi rasa aman. Kemudian pada baris pearson correlation dapat dilihat bahwa kontrol akses memiliki nilai 0,568 yang berarti korelasi yang dibentuk antara kontrol akses dengan persepsi rasa aman adalah sedang dan memiliki hubungan yang positif, sehingga ketika penerapan kontrol akses meningkat maka persepsi rasa aman juga meningkat, begitu juga sebaliknya. 
Pada variabel pengawasan dapat dilihat pada Tabel 4.1 hubungan antara pengawasan yang diterapkan di perumahan Wisma Permai Timur dengan persepsi rasa aman diperoleh nilai Sig. (2-tailed) sebesar 0.000 yang berarti kurang dari 0,05, artinya Ho ditolak, dan Ha (Terdapat hubungan antara pengawasan terhadap rasa aman penghuni perumahan Wisma Permai Timur) diterima. Jadi terdapat hubungan antara pengawasan yang diterapkan di perumahan Wisma Permai Timur dengan persepsi rasa aman. Kemudian pada baris pearson correlation dapat dilihat bahwa kontrol akses memiliki nilai 0,462 yang berarti korelasi yang dibentuk antara pengawasan dengan persepsi rasa aman adalah sedang dan memiliki hubungan yang positif, sehingga ketika penerapan pengawasan meningkat maka persepsi rasa aman juga meningkat, begitu juga sebaliknya.

Pada variabel penguatan teritori dapat dilihat pada Tabel 4.1 hubungan antara penguatan teritori yang diterapkan di perumahan Wisma Permai Timur dengan persepsi rasa aman diperoleh nilai Sig. (2-tailed) sebesar 0.000 yang berarti kurang dari 0,05 , artinya Ho ditolak, dan Ha (Terdapat hubungan antara penguatan teritori terhadap rasa aman penghuni perumahan Wisma Permai Timur) diterima. Jadi terdapat hubungan antara penguatan teritori yang diterapkan di perumahan Wisma Permai Timur dengan persepsi rasa aman. Kemudian pada baris pearson correlation dapat dilihat bahwa kontrol akses memiliki nilai 0,682 yang berarti korelasi yang dibentuk antara penguatan dengan persepsi rasa aman adalah kuat dan memiliki hubungan yang positif, sehingga ketika penerapan penguatan teritori meningkat maka persepsi rasa aman juga meningkat, begitu juga sebaliknya.

Tabel 7.

\begin{tabular}{ccccc}
\multicolumn{5}{c}{ Model Summary Uji Regresi } \\
\hline \hline Model & $\mathrm{R}$ & R Square & $\begin{array}{c}\text { Adjusted R } \\
\text { Square }\end{array}$ & $\begin{array}{c}\text { Std. Error og the } \\
\text { Estimate }\end{array}$ \\
\hline 1 & $.743^{\mathrm{a} .553}$ & .553 & .537 & 3.926 \\
\hline \hline
\end{tabular}

a. Predictors: (Constant), Penguatan Teritori, Pengawasan, Kontrol Akses Sumber : Output SPSS 2018

Dapat dilihat pada Tabel model summary, tertera nilai $\mathrm{R}$ sebesar 0,743. Hal ini menunjukan hubungan yang kuat antara kontrol akses, pengawasan, penguatan teritori terhadap persepsi rasa aman. Selain itu, nilai R menunjukan angka yang positif. Maka ketika nilai kontrol akses, pengawasan, dan penguatan teritori bertambah maka persepsi rasa aman penghuni perumahan pun akan meningkat. Begitu juga sebaliknya ketika nilai kontrol akses, pengawasan, dan penguatan teritori berkurang maka persepsi rasa aman penghuni perumahan pun akan menurun.

Kuat lemahnya hubungan dua variabel ditunjukkan oleh nilai Pearson Correlation (R) dimana nilai secara umum dibagi menjadi sbb:

$0-0.25$ korelasi sangat lemah

$0.25-0.50$ korelasi moderat

$0.50-0.75$ korelasi kuat

$0.75-1.00$ korelasi sangat kuat

Dapat dilihat pula nilai Adjusted $R$ Square yaitu sebesar 0,537 atau $54 \%$. Hal ini menunjukan bahwa presentase pengaruh variabel independen yaitu kontrol akses, pengawasan, dan penguatan teritori terhadap variabel dependen atau persepsi rasa aman sebesar 54\%. Atau

variabel independen mampu menjelaskan sebesar 54\% variasi variabel dependen. Sedangkan sisanya sebesar $46 \%$ dipengaruhi atau dijelaskan oleh variabel lain yang tidak dimasukan dalam model penelitian ini.

\section{KESIMPULAN}

Penerapan kontrol akses dapat dilihat dari terdapatnya pagar pembatas di sekeliling perumahan, terdapatnya pintu gerbang untuk akses keluar masuk di bagian barat dan timur perumahan, terdapat bentang alam yaitu sungai kalimas, serta bentang buatan berupa tembok besar yang membatasi perumahan dengan perumahan dharmahusada mas, dan adanya pemeriksaan di pintu akses oleh petugas keamanan

Penerapan pengawasan dapat dilihat dari terdapatnya penggunaan fasilitas tambahan, lalu sistem patroli, dan keberadaan petugas. Penerapan langkah pengawasan juga dapat dilihat dari kondisi penghijuan yang mendukung proses berlangsungnya pengawasan ke lingkungan sekitar perumahan. Kondisi perumahan yang sepi dsn jsuh dari kantor polisi serta kondisi penerangan yang kurang baik pada malam hari merupakan beberapa celah yang dapat dimanfaatkan oleh pelaku potensial kejahatan

Berdasarkan hasil pengamatan di lokasi penelitian adapun penerapan langkah-langkah penguatan teritori yang ada di perumahan wisma permai timur bukan hanya pada aspek fisik melainkan aspek sosial seperti kegiatan bersama antar penghuni.

Berdasarkan hasil rekap kuesioner dan metode skoring seluruh penerapan variabel CPTED dan rasa aman menu jukan bahwa penilaian responden adalah seluruhnya mewakili tingkat penerapan yang tinggi

Dari hasil uji korelasi yang dilakukan didapati hasil pearson correlation menunujukan bahwa keseluruhan variabel independen yaitu kontrol akses, pengawasan, dan penguatan teritori memiliki hubungan terhadap variabel rasa aman. Adapun hubungan yang terbentuk untuk variabel kontrol akses dan pengawasan adalah sedang, sedangkan untuk penguatan teritori adalah kuat.

Dari hasil uji regresi didapati tertera nilai R sebesar 0,743. Hal ini menunjukan hubungan yang kuat antara kontrol akses, pengawasan, penguatan teritori terhadap persepsi rasa aman.

Dapat dilihat pula nilai Adjusted $R$ Square yaitu sebesar 0,537 atau 54\%. Atau variabel independen mampu menjelaskan sebesar $54 \%$ variasi variabel dependen. Sedangkan sisanya sebesar $46 \%$ dipengaruhi atau dijelaskan oleh variabel lain yang tidak dimasukan dalam model penelitian ini

Meninjau dari serangkaian hasil pengujian korelasi dan regresi yang telah dilakukan diatas, maka dapat disimpulkan pula bahwa penerapan konsep Crime Prevention Through Enviromental Design atau CPTED mempengaruhi persepsi rasa aman penghuni perumahan Wisma Permai Timur

\section{DAFTAR PUSTAKA}

O. Newman, Defensible Space, People And Design in The Violent City. London: Architectural Press, 1972.

Badan Pusat Statistik, "Surabaya Dalam Angka 2015," Surabaya, 2016.

O. Newman, "Creating Defensible Space,” Washington D.C., 1992.

A. Schaim, "Feeling safe \& Being Safe," impactpersonalsafety.org, 
2011.

[Online].

Available: http://www.impactpersonalsafety.org/2011/10/feeling-safe-being-sa fe/. [Accessed: 15-Oct-2017].

[5] C. Jeffery, Crime Prevention Through Environmental Design. Beverly Hills: Sage Publications, 1977.
[6] T. Crowe, Crime Prevention Through Environmental Design : Applications of Architectural Design and Space Management Concepts. USA: Butterworth-Heinemann, 2000. 